\title{
Characterization of Leaf Gas Exchange and Anti-oxidant Defense of Rice (Oryza sativa L.) Cultivars Differing in Submergence Tolerance Owing to Complete Submergence and Consequent Re-aeration
}

\author{
Debabrata Panda $\cdot$ Ramani K. Sarkar
}

Received: 7 March 2012 / Accepted: 3 September 2013/Published online: 15 October 2013

(C) NAAS (National Academy of Agricultural Sciences) 2013

\begin{abstract}
The impact of submergence on the photosynthesis and antioxidant capacities in three Indica rice cultivars namely FR 13A, IR 42, and Sabita having differential response to flooding were examined under 8 days (d) of complete submergence and subsequent re-aeration for $24 \mathrm{~h}$. All upon three genotypes showed inhibition of $\mathrm{CO}_{2}$ photosynthetic rate due to complete submergence; this was accompanied with the decrease in the Rubisco activity, stomatal conductance $\left(g_{s}\right)$, and leaf chlorophyll $(\mathrm{Chl})$ content. These parameters decreased further after $24 \mathrm{~h}$ of re-aeration. The decrease was more pronounced in sensitive cultivar, IR 42, and elongating type cultivar, Sabita. Sensitivity of elongating type cultivar under complete submergence was alike to submergence sensitive type cultivar. The activities of antioxidant enzymes such as superoxide dismutase, catalase, guaiacol peroxidase, ascorbate peroxidase, dehydroascorbate reductase, and glutathione reductase and levels of ascorbate were found to be significantly high in tolerant cv. FR 13A during submergence and subsequent re-aeration period. This study indicates that the suppression of $\mathrm{CO}_{2}$ photo-assimilation under submergence was not only due to decrease of $g_{s}$ and leaf chlorophyll content but mainly due to the inhibition of rubisco activity. A greater protection of the photosynthetic system was observed through antioxidant system, since the degree of protection was more, when the levels of ascorbate and the activities of antioxidant enzymes were high.
\end{abstract}

Keywords Antioxidants $\cdot$ Chlorophyll $\cdot$ Photosynthesis $\cdot$ Rice $\cdot$ Submergence

\begin{abstract}
Abbreviations
APX: Ascorbate peroxidase (EC 1.11.1.11); CAT: Catalase (EC 1.11.1.6); Chl: Chlorophyll; CPK: Creatine phosphokinase; cv: Cultivar; d: Days; DCPIP: 2,6-Dichlorophenol indophenols; DHAR: Dehydroascorbate reductase (EC 1.8.5.1); DNPH: 2,4-Dinitrophenyl hydrazine; DTT: Dithiothreitol; FW: Fresh weight; GAPDH: Glyceraldehydes-3phosphate dehydrogenase; GPX: Guaiacol peroxidase (EC 1.11.1.7); GR: Glutathione reductase (EC 1.6.4.2); $g_{s}$ : Stomatal conductance; HEPES4: 4-(2-Hydroxyethyl) piperazine-1-ethanesulfonic acid; MDA: Malondialdehyde; PGK: 3Phosphoglyceric phosphokinase; Rubisco: Ribulose 1,5-bisphosphate carboxylase/oxygenase; RUBP: Ribulose 1,5bisphosphate; SOD: Superoxide dismutase (1.15.1.1); TBA: Thiobarbituric acid
\end{abstract}

D. Panda $\cdot$ R. K. Sarkar

Division of Biochemistry, Plant Physiology and Environmental

Sciences, Central Rice Research Institute, Cuttack 753 006,

Orissa, India

Present Address:

D. Panda $(\bowtie)$

Centre for Biodiversity and Conservation of Natural Resources,

Central University of Orissa, Koraput 764 020, India

e-mail: dpanda80@gmail.com

\section{Introduction}

Rice is often the only cereal that can be grown in flood prone ecosystem. Analysis of flooding pattern in rainfed lowland of Southeast Asia reveals that about 20 million ha comes under medium-deep to deep and very deep ecology based on water stagnation. Here, the ideal response to flooding is submergence tolerance (survival under water) 
together with some elongating ability [4, 30, 32]. Is the extent of injury caused by complete submergence is alike both in tolerant and elongating type rice cultivars? Recent discovery of SUB1 QTL from FR13A have given impetus in developing cultivars tolerant to complete submergence and associated tolerance mechanism studies [14, 32]. Besides, the genetic makeup the extent of injury caused by complete submergence is also depend on floodwater conditions, particularly its temperature, turbidity, and the extent of light penetration [10]. The $10^{4}$-fold reduction in diffusion of gases in water relative to air limits the exchange of carbon dioxide and oxygen necessary for photosynthesis and respiration [23]. When rice plants are subjected to flash floods they should adapt themselves to two drastic environmental changes: the changes from aerobic to hypoxic condition during complete submergence and the subsequent changes from hypoxic to aerobic conditions when the flood water recedes. The visual damage caused by the submergence is generally not apparent immediately but develops soon after the water level recedes after complete submergence [11]. It is generally assumed that submergence causes closure of stomata and impairs gas exchange and $\mathrm{CO}_{2}$ assimilation further it induces photo bleaching of chlorophylls due to oxidative stress $[12,22,31]$. Flooding/submergence and re-oxygenation can induce oxidative stress causing an increased production of reactive oxygen species (ROS) [12, 36]. Submergence promotes rapid accumulation of ROS, which function as signaling molecules to trigger diverse acclimation responses to the stresses [14]. Plants have active oxygen-scavenging systems consisting of several antioxidant enzymes and some low molecules of non enzyme antioxidants, which can neutralize the free radicals and thus retard the progress of many injuries associated with oxidative stress and ROS [9]. Among all the antioxidant enzymes, superoxide dismutase (SOD), catalase (CAT), ascorbate peroxidase (APX), guaiacol peroxidase (GPX), glutathione reductase (GR), and dehydroascorbate reductase (DHAR) play key roles protecting plants from oxidative stress damage [3]. It is generally assumed that submergence causes closure of stomata and impairs gas exchange and $\mathrm{CO}_{2}$ assimilation further it induces photo bleaching of $\mathrm{Chl}$ due to oxidative stress [19].

Although the activities of antioxidative enzymes by submergence stress in rice cultivars as already shown in other research $[9,12,15]$ and responses to a specific stress may vary with the genotype; nevertheless, some general reactions occur in all genotypes. The aim of the present investigation was to compare the photosynthetic performance and antioxidant defense in elongating and nonelongating type cultivar under submergence and subsequent re-aeration. Since submergence imposes hypoxic condition thus antioxidant enzymes and the level of antioxidants were also evaluated to know the association of these enzymes with photosynthetic process in rice as affected by complete submergence and subsequent re-aeration.

\section{Materials and Methods}

\section{Plant Material and Growth Conditions}

The study was conducted by taking three Indica rice cultivars namely FR 13A, IR 42, and Sabita having differential response to flooding. FR 13A, which is known to be tolerant to complete submergence and IR 42, which is susceptible, have been used in many physiological studies $[12,22]$. Sabita, a local cultivar that elongates fast under complete submergence and survives if leaf tips remain above the water surface was also examined to ascertain the physiological changes, which it undergoes, resemble likely elongating type under complete submergence.

The three cultivars were sown directly in earthen pots containing $2 \mathrm{~kg}$ of farm soil and farmyard manure in a $3: 1$ ratio [22]. Each pot was supplied with $88 \mathrm{mg}$ urea, $190 \mathrm{mg}$ single super phosphate, and $50 \mathrm{mg}$ murate of potash. 10 days after germination, the seedlings were thinned and five plants per pot were maintained. Plants were grown in a greenhouse subjected to natural solar radiation, with daily maximum photosynthetic photon flux density, air temperature, and relative humidity being about $1,650 \mu \mathrm{mol} \mathrm{m} \mathrm{m}^{-2} \mathrm{~s}^{-1}$ and $32.5^{\circ} \mathrm{C}$ and $70-75 \%$, respectively. The pots containing 21-day-old seedlings were completely submerged in concrete tanks filled with water to a height of $110 \mathrm{~cm}$ such that at least $50 \mathrm{~cm}$ of water column remained above the top of the plants. This complete submergence imposed severe stress on the plants. The plants were maintained under three treatments: (1) complete submergence for 8 days, (2) complete submergence for 8 days followed by aeration for 1 day, and (3) control growth condition, i.e., without submergence treatment. For re-aeration the height of water column was brought down to $10 \mathrm{~cm}$ from the level of $110 \mathrm{~cm}$. The experiments were carried out in three replications and were statistically analyzed.

The characteristics of the floodwater in terms of light transmission were measured at $12 \mathrm{~h}$ (LI-COR, Lincoln, USA), and water temperature and oxygen concentration were determined at 6 and $17 \mathrm{~h}$ (Syland, Heppenheim, Germany) every alternate days. Light intensity at $60 \mathrm{~cm}$ water depth or at the vicinity of canopy level ranged from 205 to 315 $\mu \mathrm{mol} \mathrm{m} \mathrm{m}^{-2}$, whereas it was $1,723-1,818 \mu \mathrm{mol} \mathrm{m} \mathrm{m}^{-2} \mathrm{~s}^{-1}$ above the water surface. The oxygen concentration at the same water depth was $2.3-3.2 \mathrm{mg} \mathrm{L}^{-1}$ at $6 \mathrm{~h}$ and $4.2-5.6 \mathrm{mg} \mathrm{L}^{-1}$ at $17 \mathrm{~h}$. The temperature did not vary much, being 25.6-29.5 ${ }^{\circ} \mathrm{C}$ throughout the period of the experiment. To study the effect of submergence on subsequent re-aeration, we selected the leaves, which experienced full submergence stress. 
Measurement of Carbon Dioxide Photosynthetic Rate and Stomatal Conductance

Measurements of $\mathrm{CO}_{2}$ photosynthetic rate $\left(\mathrm{P}_{N}\right)$ and stomatal conductance $\left(g_{s}\right)$ were made on the fully expanded leaves of five different plants within $30 \mathrm{~min}$ at the end of submergence treatment using an open system photosynthetic gas analyzer (model TPS-1, PP Systems, USA) under ambient environmental conditions as reported in Panda et al. [23]. The second and third leaf from the top was selected and kept inside the chamber under natural irradiance until stable reading was documented.

\section{Chlorophyll Content}

For Chl estimation, $100 \mathrm{mg}$ of finely chopped fresh leaves were placed in a $25 \mathrm{~mL}$ capped-measuring tube containing $25 \mathrm{~mL}$ of $80 \%$ cold acetone, and kept dark inside a refrigerator $\left(4{ }^{\circ} \mathrm{C}\right)$ for $48 \mathrm{~h}$ [29]. The $\mathrm{Chl}$ was measured spectrophotometrically by taking optical density at 663.6 and $646.6 \mathrm{~nm}$ following Porra [26]. The Chl $a$ and $b$ contents were calculated using the following equations.

Chlorophyll $a\left(\mu \mathrm{g} \mathrm{ml}^{-1}\right)=12.25(\mathrm{~A} 663.6)-2.55(\mathrm{~A} 646.6)$,

Chlorophyll $b\left(\mu \mathrm{g} \mathrm{ml}^{-1}\right)=20.31(\mathrm{~A} 646.6)-4.91(\mathrm{~A} 663.6)$.

\section{Rubisco Activities}

The activity of Rubisco (EC 4.1.1.39) was estimated following the method of Yu-Chun et al. [37] with minor modifications. The leaves collected per pot were chopped and mixed, which constituted one replication. A representative sample of fresh leaves weighing $500 \mathrm{mg}$ were homogenized in a chilled mortar with $30 \mathrm{mg}$ insoluble polyvinyl pyrrolidone, $0.2 \mathrm{~g}$ sea sand and $4 \mathrm{~mL}$ extraction buffer (100 mM Tris-HCl, pH 7.8), 1 mM EDTA-NaOH (pH 7.0), $5 \mathrm{mM}$ DTT, $0.2 \%$ BSA. The homogenate was centrifuged at $15,000 \times g$ for $5 \mathrm{~min}$; the supernatant was used immediately for the determination of Rubisco activity. All processes were conducted within $0-4{ }^{\circ} \mathrm{C}$. Rubisco was assayed at $30^{\circ} \mathrm{C}$ in a medium containing $50 \mathrm{mM}$ Hepes-KOH buffer ( $\mathrm{pH} 8.0$ ), $10 \mathrm{mM} \mathrm{NaHCO} 3,0.2 \mathrm{mM}$ $\mathrm{NADH}, 2.5 \mathrm{mM}$ ATP, $10 \mathrm{mM} \mathrm{KCl}, 1 \mathrm{mM}$ EDTA-NaOH buffer (pH 7.0), $20 \mathrm{mM} \mathrm{MgCl}_{2}, 5 \mathrm{mM}$ DTT, $5 \mathrm{mM}$ phospho creatine, $6 \mathrm{U} \mathrm{mL}^{-1}$ PGK and GAPDH each, $20 \mathrm{U} \mathrm{mL}^{-1} \mathrm{CPK}$, and $50 \mu \mathrm{L}$ of leaf extract. The reaction mixture was incubated for $10 \mathrm{~min}$ at $28{ }^{\circ} \mathrm{C}$ without $\mathrm{RuBP}$ (substrate), which was added to initiate the reaction with a concentration of $0.6 \mathrm{mM}$ in a final volume of $1 \mathrm{~mL}$. The absorbance at $340 \mathrm{~nm}$ for NADH without RUBP was taken as baseline. The activity was expressed as $\mu$ mol NADH oxidized $\min ^{-1} \mathrm{~g}^{-1}$ fresh weight by using extinction coefficient of $6.22 \mu \mathrm{mol} \mathrm{cm} \mathrm{cm}^{-1}$.

\section{Antioxidant Enzyme Activity}

Leaf sample weighing $500 \mathrm{mg}$ was homogenized in $10 \mathrm{~mL}$ of $50 \mathrm{mM}$ potassium phosphate buffer ( $\mathrm{pH} 7.8)$ containing $1 \mathrm{mM}$ EDTA, $1 \mathrm{mM}$ ascorbate, $10 \%$ (w/v) sorbitol, and $0.1 \%$ tritron $\mathrm{X}-100$. The homogenate was centrifuged at $4{ }^{\circ} \mathrm{C}$ at $15,000 \times g$ for $20 \mathrm{~min}$ and the supernatant was used for enzyme analysis. All operations were performed at $0-4{ }^{\circ} \mathrm{C}$.

SOD (EC 1.15.1.1) was measured by the photochemical method described by Giannopolitics and Ries [16] with modifications suggested by Choudhury and Choudhury [8]. $3 \mathrm{~mL}$ reaction mixture contained $2.4 \mathrm{~mL}(50 \mathrm{mM}) \mathrm{Na}_{2}$ $\mathrm{PO}_{4}$ buffer ( $\mathrm{pH} 7.8$ ) containing $0.1 \mathrm{mM}$ EDTA, $63 \mu \mathrm{M}$ nitro blue tetrazolium chloride (NBT) and $13 \mu \mathrm{M} \mathrm{L-}$ methionine, $0.2 \mathrm{~mL}$ of enzyme extract, and $0.5 \mathrm{~mL}$ riboflavin $(1.3 \mu \mathrm{M})$. Riboflavin was added last. The reaction was monitored in the presence of two $40 \mathrm{~V}$ fluorescent lamp for $20 \mathrm{~min}$. $1 \mathrm{U}$ of SOD activity was defined as the amount of enzyme that caused $50 \%$ inhibition of the rate of NBT reduction at $560 \mathrm{~nm}$ using a spectrophotometer (model SL 164 double beam, ELICO, Hyderabad, India). CAT activity was measured in a reaction mixture containing $25 \mathrm{mM}$ phosphate buffer ( $\mathrm{pH} 7.0$ ), $10 \mathrm{mM} \mathrm{H}_{2} \mathrm{O}_{2}$ and the enzyme extract. The decomposition of $\mathrm{H}_{2} \mathrm{O}_{2}$ was followed at $240 \mathrm{~nm}$ [7]. APX (EC 1.11.1.11) was assayed following Nakano and Asada [20] by monitoring the rate of ascorbate oxidation at $290 \mathrm{~nm}$ by using extinction coefficient $=2.8 \mathrm{mmol} \mathrm{cm}^{-1}$. The reaction mixture contained $50 \mathrm{mM}$ potassium phosphate buffer $(\mathrm{pH} 7.0), 0.1 \mathrm{mM}$ EDTA, $100 \mathrm{mM} \mathrm{H}_{2} \mathrm{O}_{2}$, and $0.5 \mathrm{mM}$ ascorbic acid and the enzyme aliquot. The activity of GPX (EC 1.11.1.7) was assayed following the method of Rao et al. [28]. The reaction mixture contained $50 \mathrm{mM}$ phosphate buffer $(\mathrm{pH}$ 7.0), $0.1 \mathrm{mM}$ guaiacol, $0.1 \mathrm{mM} \mathrm{H}_{2} \mathrm{O}_{2}$, and the enzyme aliquot. Enzyme activity was measured by the increase in absorbance at $470 \mathrm{~nm}$ caused by guaiacol oxidation by using extinction coefficient $=26.6 \mathrm{mM} \mathrm{cm}^{-1}$. GR $(\mathrm{EC}$ 1.6.4.2) was assayed according to the method of Foyer and Halliwell [13] by following the decrease in absorbance at $340 \mathrm{~nm}$ caused by NADPH oxidation by using extinction coefficient $=6.2 \mathrm{mM} \mathrm{cm}^{-1}$. DHAR (EC 1.8.5.1) was assayed following Nakano and Asada [20] by measuring the increase in absorbance at $265 \mathrm{~nm}$.

\section{Ascorbate Content}

Ascorbic acid content was determined following Shigeoka et al. [33]. Fresh leaf sample weighing $500 \mathrm{mg}$ was homogenized in $3 \mathrm{~mL} 5 \%$ (w/v) meta-phosphoric acid. 
The extract was clarified by centrifugation at $2,000 \times g$ for $20 \mathrm{~min}$ at $4{ }^{\circ} \mathrm{C}$ and the supernatant was used for the assay. An aliquot measuring $0.5 \mathrm{~mL}$ was mixed with $0.25 \mathrm{~mL}$ of $3 \mathrm{mM}$ DCPIP to measure the total ascorbic acid content, whereas an equal volume of water was added when the oxidized ascorbic acid content was to be measured. After keeping the mixture at room temperature for $20 \mathrm{~min}$ $0.5 \mathrm{~mL}$ of $1 \%(\mathrm{w} / \mathrm{v})$ thiourea in $5 \%(\mathrm{w} / \mathrm{v})$ meta-phosphoric acid and $0.5 \mathrm{~mL}$ of DNPH was added. The mixture was then incubated at $50{ }^{\circ} \mathrm{C}$ for $1 \mathrm{~h}$, cooled in an ice bath for 15 min while adding $1.2 \mathrm{~mL}$ of ice cold $85 \% \mathrm{H}_{2} \mathrm{SO}_{4}$. Then absorbance at $520 \mathrm{~nm}$ was recorded using a spectrophotometer (model SL 164 double beam, ELICO, Hyderabad, India). The amount of reduced ascorbate was calculated by subtracting oxidized ascorbate content from total ascorbate.

\section{Lipid Peroxidation}

Lipid peroxidation was measured as the amount of malondialdehyde (MDA) produced by thiobarbituric acid (TBA) reaction, as described by Heath and Packer [18]. Fresh leaf sample weighing $500 \mathrm{mg}$ was homogenized in $10 \mathrm{~mL}$ of $0.1 \%$ (w/v) trichloro acetic acid (TCA). The homogenate was centrifuged at $10,000 \times g$ for $20 \mathrm{~min}$. To $4 \mathrm{~mL}$ of $20 \%$ TCA containing $0.5 \%$ (w/v) TBA was added to $1 \mathrm{~mL}$ of supernatant. The mixture was heated at $95{ }^{\circ} \mathrm{C}$ for $30 \mathrm{~min}$ and was then quickly cooled in ice. The contents were centrifuged at $10,000 \times g$ for $15 \mathrm{~min}$ and the absorbance was measured at $532 \mathrm{~nm}$. The value of nonspecific absorption was subtracted. The concentration of MDA was calculated using an extinction coefficient of $155 \mathrm{mM}^{-1} \mathrm{~cm}^{-1}$.

\section{Statistical Analysis}

Differences between various physiological and biochemical parameters were compared by ANOVA using IRRISTAT (International Rice Research Institute, Philippines) software's least significant difference (LSD, $* P<0.05$ ), as this is a good test for determining whether means were significantly different. Correlation coefficients and regression analysis were done following the standard procedure.

\section{Results}

Survival and Shoot Elongations Under Submergence

In this experiment, the three cultivars gave distinctly different response to submergence in terms of survival and shoot elongation. Tolerant cv. FR 13A showed $100 \%$ survival after 8 days of submergence, whereas it was less than $15 \%$ in IR 42 and Sabita (data not given).

Plant height increased due to submergence in all the cv but the elongation was greater in Sabita and IR42 compared to FR13A. After 8 days of submergence, the increase in plant height was more than $98 \%$ in Sabita, $65 \%$ in IR42 and only $34 \%$ in FR13A compared to the non submerged control plant (data not given).

\section{Chl Loss During Submergence}

Submergence resulted in significant reduction of Chl content in both susceptible and tolerant cultivars (Table 1). However, tolerant cv. FR 13A maintained significantly higher amount of $\mathrm{Chl}$ during submergence and subsequent period of re-aeration compared to IR 42 and Sabita. The percentage reduction was more in IR $42(65 \%)$ followed by Sabita (36 \%) and FR13A (19\%). The level of Chl was more or less same in all the cultivars compared to inundated seedlings after $24 \mathrm{~h}$ of re-aeration.

\section{$\mathrm{P}_{N}, g_{s}$, and Rubisco Activity}

After 8 days of submergence there was a substantial reduction in $\mathrm{P}_{N}$ with maximum reduction in IR $42(89 \%)$, followed by Sabita (84\%), and FR 13A (47\%) in comparison to non-submerged control plants (Table 1). On subsequent re-aeration for $24 \mathrm{~h} \mathrm{P}_{N}$ further decreased with greater reduction in IR 42 (99\%), followed by Sabita $(95 \%)$ and FR 13A (66\%). Like $\mathrm{P}_{N}, g_{s}$ were also significantly reduced under submergence. Further, reduction occurred during air-adaptation (Table 1). The reduction was found to be 38,75 , and $73 \%$ after 8 days of submergence and 44, 94, and $92 \%$ after $24 \mathrm{~h}$ of re-aeration in FR 13A, IR 42, and Sabita, respectively. Similarly the activities of Rubisco decreased due to submergence treatment (Table 1). The level of reduction was more in susceptible cultivar compared to the tolerant cultivar. The decrease in Rubisco activities was 20, 84, and $72 \%$ after 8 days of submergence and 69,94 , and $78 \%$ after $24 \mathrm{~h}$ of re-aeration in FR 13A, IR 42, and Sabita, respectively, in compared to the control plants.

\section{Antioxidant Enzymes, Ascorbate Content and Lipid} Peroxidation

Submergence caused reduction in activities of antioxidant enzymes in both tolerant and susceptible cultivars (Fig. 1). Under submergence the activities of the antioxidant enzymes namely, SOD, CAT, GPX, APX, DHAR, and GR were significantly greater in tolerant cultivar compared to the susceptible cultivars. After exposure to air the activities of all the antioxidant enzymes increased with greater 
Table 1 Changes of leaf Chl content ( $\left.\mathrm{mg} \mathrm{g}^{-1} \mathrm{FW}\right)$, Rubisco ( $\mu \mathrm{mol}$ NADH oxidized $\left.\mathrm{min}^{-1} \mathrm{~g}^{-1} \mathrm{FW}\right)$ activity, $g_{s}\left(\mathrm{mmol} \mathrm{m}^{-2} \mathrm{~s}^{-1}\right)$, and $\mathrm{P}_{N}[\mu \mathrm{mol}$ $\left(\mathrm{CO}_{2}\right) \mathrm{m}^{-2} \mathrm{~s}^{-1}$ ] in rice leaves under submergence and subsequent period of re-aeration

\begin{tabular}{|c|c|c|c|c|c|c|c|c|c|c|c|c|}
\hline \multirow[t]{2}{*}{ Cultivars } & \multicolumn{3}{|l|}{ Chl } & \multicolumn{3}{|c|}{ Rubisco } & \multicolumn{3}{|l|}{$g_{s}$} & \multicolumn{3}{|l|}{$\mathrm{P}_{N}$} \\
\hline & $\mathrm{C}$ & S & RA & $\mathrm{C}$ & $\mathrm{S}$ & RA & $\mathrm{C}$ & S & RA & $\mathrm{C}$ & S & RA \\
\hline FR13A & 1.6 & 1.3 & 1.4 & 11.1 & 8.9 & 3.5 & 190 & 138 & 127 & 28.6 & 15.0 & 10.0 \\
\hline IR 42 & 1.4 & 0.5 & 0.4 & 9.5 & 1.1 & 0.6 & 108 & 27 & 7 & 23.6 & 2.7 & 0.3 \\
\hline Sabita & 1.4 & 0.9 & 0.8 & 10.1 & 2.9 & 2.3 & 109 & 30 & 9 & 21.3 & 3.6 & 1.1 \\
\hline LSD $* P<0.05$ & 0.2 & & & 1.3 & & & 23 & & & 2.9 & & \\
\hline
\end{tabular}

Chl content includes both $\mathrm{Chl} a$ and $b$. The measurement of $\mathrm{P}_{N}$ was carried out on fully expanded mature leaves at $30 \pm 2{ }^{\circ} \mathrm{C}, 70 \% \mathrm{RH}$, $1,253 \pm 42 \mu \mathrm{mol} \mathrm{m} \mathrm{m}^{-2} \mathrm{~s}^{-1}$ photosynthetic active radiation, $370 \mu \mathrm{mol}\left(\mathrm{CO}_{2}\right) \mathrm{m}^{-2} \mathrm{~s}^{-1}$ concentration and $21 \% \mathrm{O}_{2}$. Data are the mean of three replicates. Each replication had five measurements

$L S D * P<0.05, C$ control without submergence, $S$ submergence for 8 days, $R A$ complete submergence for 8 days followed by aeration for 1 day

magnitude in tolerant cultivar. Both total and reduced ascorbate content significantly decreased under submergence in all the cultivars compared to the control plant (Table 2). The tolerant cv. FR 13A maintained higher levels of both total as well as reduced ascorbate content during submergence and subsequent period of re-aeration.

MDA is one of the products of plant lipid peroxidation, and its level reflects the level of lipid peroxidation, resulting from oxidative stress induced damage to membrane. The MDA content found to be significantly increased in all the cultivar during submergence and subsequent period of re-aeration compared to the control plant (Table 2). The MDA content was more increased in susceptible and avoiding type cv. compared to tolerant $\mathrm{cv}$.

Correlation of Antioxidants with Photosynthetic Parameters

There was highly significant positive association of antioxidant enzyme activities with $\mathrm{Chl}$ content, Rubisco activity, and $\mathrm{P}_{N}$. The levels of ascorbate also showed highly significant correlation with $\mathrm{Chl}$ content, Rubisco activity, and $\mathrm{P}_{N}$ (Table 3 ).

\section{Discussion}

Under natural flooding, in general, hypoxic condition prevails especially at night and early hours of the day, when plants absorb $\mathrm{O}_{2}$ for respiration and photosynthetically production of the $\mathrm{O}_{2}$ is stopped. While during day time the concentration of oxygen in floodwater varies from hypoxic to super-saturation levels depending upon the photosynthesis of submerged rice plants or other submerged plant species [27]. As diffusion of gasses is 10,000 times lower in water compared to the air [2], the plants are exposed with different levels of $\mathrm{O}_{2}$ during submergence. Besides $\mathrm{O}_{2}$, another environmental constraint that plant has to encounter during submergence is the low irradiance. Water logging/submergence can induce oxidative stress in rice causing an increased production of ROS reported in many studies [9, 12, 15]. The ROS act as a cellular indicator of submergence stress and as secondary messenger involved in the stress response signal transduction pathway [14]. These ROS not only have the direct harmful effect of photosynthesis but also contribute the repulsion of many photosynthetic genes [25]. These environmental complexities might reduce the concentration of $\mathrm{Chl}$ and simultaneously decrease the photosynthetic capacity and plants succumb to die. When plants are submerged the anoxic/ hypoxic condition inhibits aerobic respiration and less energy is yielded. Several other factors like Chl breakdown, lipid peroxidation, stomatal closure, and low internal $\mathrm{CO}_{2}$ concentration were results a concomitant decline in photosynthesis. Reduction in $\mathrm{CO}_{2}$ concentration and increase in the amount of ROS within the leaf due to ongoing light reaction, which leads to senescence and even death of the plants [19]. High level of some antioxidant enzymes such as SOD, CAT, APX, GR, GPX are important in order to survive oxidative stress after the plants are subjected to different levels of water logging [19]. Our study clearly shows that submergence significantly inhibits the $\mathrm{P}_{N}$ (Table 1). Along with the $\mathrm{P}_{N}$ there was an inhibition of $g_{s}$ and Rubisco activity (Table 1). Various possible causes of photosynthetic reductions of water-logged plants can be considered, including abscisic acid, ethylene, and active oxygen species [1]. The change in net carbon assimilation under flooding was attributed to stomatal and non-stomatal limitation [24]. More over decrease in photosynthesis and $g_{s}$ under submergence had been demonstrated in many species [35]. Photosynthetic activity has also been shown to be significantly inhibited under flooding due to the reduction of RuBP regeneration [6]. The maintenance of higher photosynthetic activity in tolerant cv. might be due to the protection of photosynthetic apparatus as well as the better $g_{s}$ and higher level of Chl during submergence and subsequent 

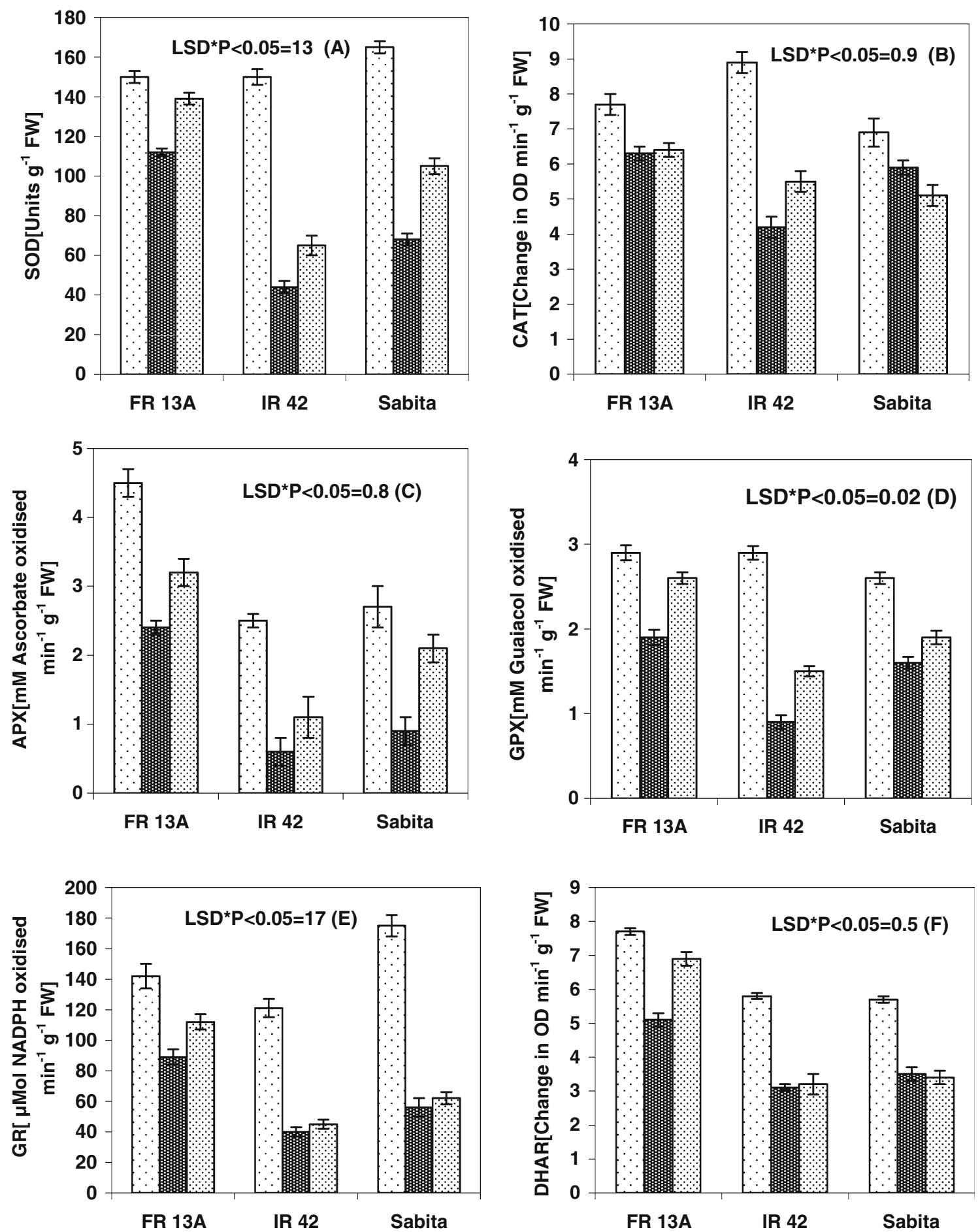

Fig. 1 Changes of antioxidant enzyme activities in rice leaves under submergence and subsequent re-aeration. The measurements were carried out on fully expanded mature leaves.

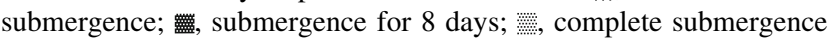

period of re-aeration compared to sensitive cv IR 42 and elongating cv Sabita (Table 1).

When floodwater recedes, submerged rice plants come across high oxygen and high light intensity relative to that

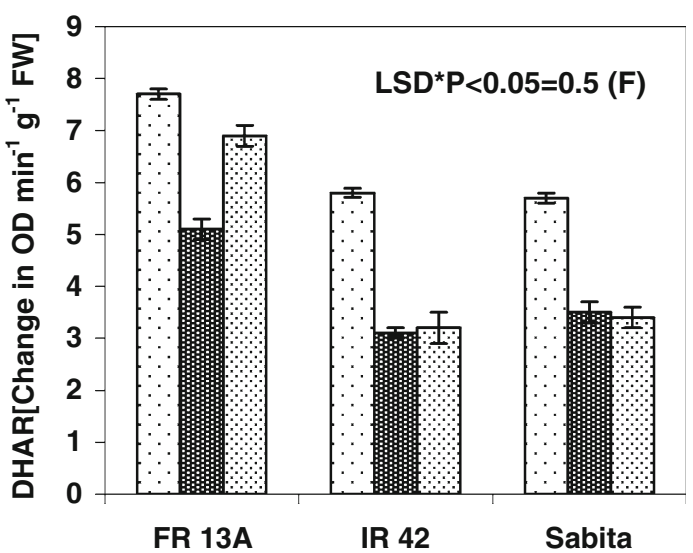

for 8 days followed by aeration for 1 day. Data are the mean of three replicates with vertical bar represents standard deviation. LSD, $* P<0.05$

of under water. It is unavoidable to escape oxidative damage in aerobic condition; therefore, plants have their own system for scavenging ROS through some antioxidant enzymes and antioxidant substances. During re-aeration, 
Table 2 Changes of total and reduced ascorbate content $\left(\mu \mathrm{g} \mathrm{g}^{-1} \mathrm{FW}\right)$ and MDA (nmol g $\left.{ }^{-1} \mathrm{FW}\right)$ content in rice leaves under submergence and subsequent re-aeration

\begin{tabular}{|c|c|c|c|c|c|c|c|c|c|}
\hline \multirow[t]{2}{*}{ Cultivars } & \multicolumn{3}{|c|}{ Total ascorbate } & \multicolumn{3}{|c|}{ Reduced ascorbate } & \multicolumn{3}{|c|}{ MDA } \\
\hline & $\mathrm{C}$ & S & RA & $\mathrm{C}$ & S & RA & $\mathrm{C}$ & S & RA \\
\hline FR13A & 692 & 280 & 299 & 292 & 65 & 29 & 19.2 & 18.6 & 21.6 \\
\hline IR 42 & 796 & 163 & 162 & 256 & 11 & 13 & 18.6 & 19.8 & 23.4 \\
\hline Sabita & 922 & 158 & 152 & 282 & 30 & 24 & 17.3 & 19.6 & 23.9 \\
\hline LSD $* P<0.05$ & 23 & & & 12 & & & 0.4 & & \\
\hline
\end{tabular}

Data are the mean of three replicates

$L S D * P<0.05, C$ control without submergence, $S$ submergence for 8 days, $R A$ complete submergence for 8 days followed by aeration for 1 day

Table 3 Correlation coefficients ( $r$ values) of Chl content, Rubisco activity, $g_{s}$ and $\mathrm{P}_{N}$ with different antioxidant enzymes and ascorbate content (ASC-T, total ascorbate; ASC-R, reduced ascorbate); $N=9$

\begin{tabular}{|c|c|c|c|c|}
\hline & Chl & $g_{s}$ & Rubisco & $\mathrm{P}_{N}$ \\
\hline SOD & $0.907 * *$ & $0.772 *$ & $0.824 * *$ & $0.836^{* *}$ \\
\hline CAT & $0.804 * *$ & $0.802 * *$ & $0.814 * *$ & $0.865 * *$ \\
\hline GPX & $0.881 * *$ & $0.755^{*}$ & $0.767 *$ & $0.828 * *$ \\
\hline APX & $0.853 * *$ & $0.864 * *$ & $0.727 *$ & $0.783^{*}$ \\
\hline GR & $0.879 * *$ & $0.791 *$ & $0.857 * *$ & $0.879 * *$ \\
\hline DHAR & $0.926 * *$ & $0.944 * *$ & $0.760^{*}$ & $0.852 * *$ \\
\hline ASC-T & $0.712 *$ & $0.628 \mathrm{~ns}$ & $0.859 * *$ & $0.890 * *$ \\
\hline ASC-R & $0.735^{*}$ & $0.689 *$ & $0.892 * *$ & $0.927 * *$ \\
\hline
\end{tabular}

Significance at $* P<0.05$, and $* * P<0.01$, respectively

$n s$ non-significant

rice seedlings need protection from ROS [5]. Potentially ${ }^{1} \mathrm{O}_{2}$ are generated in Photosynthesis-II (PS II) reaction centres and light harvesting complex (LHC) and $\mathrm{O}_{2}{ }^{-}$is generated in Photosynthesis-I (PS I) acceptor side [21]. Ascorbic acid interacts with scavenging ROS in both PS II and PS I sides through xanthophyll cycle [34] and ascorbate-glutathione cycle [9]. The significant decrease of antioxidative enzymes lilke SOD, CAT, APX, GPX, GR, and DHAR after 8 days of submergence indicating the low activity of rice leaves to decompose to $\mathrm{H}_{2} \mathrm{O}_{2}$ and superoxide radicals as has been reported for other crops [1]. Another possible cause of reduction of these enzymes is the reduction of the production and/or activity of active oxygen species. In our previous study, the damaged light reaction system was evident as decrease in PS II activity [22, 23]. This may have lead to a loss of chemical energy provided by light reaction system, which are thought to be used for the production of ROS under stressful condition, in which chemical energy are not used for the $\mathrm{CO}_{2}$ fixation. In the present study decrease in antioxidant enzymes and ascorbate content during submergence and their slow recovery after submergence in the susceptible cv. causes more oxidative damage to the susceptible cv. MDA is one of the products of plant lipid peroxidation, resulting from oxidative stress induced damage to membrane [17]. The MDA content found to be significantly higher in the susceptible and elongating $\mathrm{cv}$. showed more oxidative damage to the membrane was observed during submergence and subsequent period of re-aeration (Table 2). Our experiment showed that there were positive correlations between different antioxidant enzyme SOD, CAT, APX, GPX, GR, DHAR activities and ascorbate level with Rubisco activity and $\mathrm{P}_{N}$ (Table 3).

The results showed that tolerant cultivar, somehow maintained greater quantities of ascorbate content and antioxidant enzymes levels during submergence and subsequent period of re-aeration might help it to encounter the oxidative damage efficiently. The behavior of elongating and submergence susceptible cultivar was same during and after submergence on the basis of photosynthetic capacity and antioxidant defense mechanism. Maintenance of higher photosynthetic activity in rice during submergence and subsequent period of re-aeration might be due to the anti oxidative protection of photosynthetic apparatus and $\mathrm{Ru}$ bisco activity as well as the better $g_{s}$.

Acknowledgments Authors are grateful to Prof. Prasanna Mohanthy, Regional Pant Resource Centre, Bhubaneswar 751015, Orissa, India for his valuable suggestion.

\section{References}

1. Ahmed S, Nawata E, Hosokawa Y, Domae Y, Sakuratani T (2002) Alterations in photosynthesis and some antioxidant enzymatic activities of mung bean subjected to waterlogging. Plant Sci 163:7-123

2. Armstrong W (1979) Aeration in higher plants. Adv Bot Res $7: 225-332$

3. Asada K (1996) The role of ascorbate peroxidase and monodehydroascorbate reductase in hydrogen peroxide scavenging in plants. In: Scandalios JG (ed) Oxidative stress and the molecular biology of antioxidant defense. Cold Spring Harbor Laboratory press, NewYork, pp 715-735

4. Bailey-Serres J, Voesenek LACJ (2008) Flooding stress: acclimations and genetic diversity. Annu Rev Plant Biol 59:313-319 
5. Blokhina OB, Fagorstedt KV, Chirkova TV (1999) Relationships between lipid peroxidation and anoxia tolerance in a range of species during post anoxic reaeration. Physiol Plant 105:625-635

6. Bradford KJ (1983) Effects of soil flooding of leaf gas exchange of tomato plants. Plant Physiol 73:475-479

7. Cakmak I, Marschner H (1992) Magnessium deficiency and high light intensity enhance activities of superoxide dismutase, ascorbate peroxidase and glutathione reductase in bean leaves. Plant Physiol 98:1222-1227

8. Choudhury SR, Choudhury MA (1985) Hydrogen peroxide metabolism as an index of water stress tolerance in jute. Physiol Plant 65:503-507

9. Damanik RI, Maziah M, Ismail MR, Ahmad S, Zain AM (2010) Responses of the antioxidative enzymes in Malaysian rice (Oryza sativa L.) cultivars under submergence condition. Acta Physiol Planta 32:739-747

10. Das KK, Panda D, Sarkar RK, Reddy JN, Ismail AM (2009) Submergence tolerance in relation to variable floodwater conditions in rice. Environ Exp Bot 66:425-434

11. Drew MC (1997) Oxygen deficiency and root metabolism: injury and acclimation under hypoxia and anoxia. Ann Rev Plant Physiol Plant Mol Biol 48:223-250

12. Ella ES, Kawano N, Osamu H (2003) Importance of active oxygen scavenging system in the recovery of rice seedlings after submergence. Plant Sci 165:85-93

13. Foyer CH, Halliwell B (1976) The presence of glutathione and glutathione reductase in chloroplast: a proposed role in ascorbic acid metabolism. Planta 133:21-25

14. Fukao T, Bailey-Serres J (2004) Plant responses to hypoxia-is survival a balancing act? Trends Plant Sci 9:449-456

15. Fukao T, Yeung E, Bailey-Serres J (2011) The submergence tolerance regulator SUB1A mediates crosstalk between submergence and drought tolerance in rice. Plant Cell 23:412-427

16. Giannopolitics CN, Ries SK (1977) Superoxide dismutases: occurrence in higher plants. Plant Physiol 115:159-169

17. Guo Z, Huang M, Lu S, Yaqing Z, Zhong S (2007) Differential response to paraquat induced oxidative stress in two rice cultivars on antioxidants and chlorophyll a fluorescence. Acta Physiol Plant 29:39-46

18. Heath RL, Packer L (1968) Photo peroxidation in isolated chloroplast I. Kinetics and stochiometry of fatty acid peroxidation. Arch Biochem Biophys 125:189-198

19. Lin K-R, Weng C-C, Lo H-F, Chen J-T (2004) Study of root antioxidative system of tomatoes and egg plants under waterlogged conditions. Plant Sci 167:355-365

20. Nakano Y, Asada K (1981) Hydrogen peroxide is scavenged by ascorbate specific peroxidase in spinach chloroplasts. Plant Cell Physiol 22:867-880

21. Niyogi KK (1999) Photoprotection revisited: genetic and molecular approaches. Ann Rev Plant Physiol Plant Mol Biol 50: 333-359

22. Panda D, Rao DN, Sharma SG, Strasser RJ, Sarkar RK (2006) Submergence effect on rice genotypes during seedling stage: probing of submergence driven changes of photosystem 2 by chlorophyll a fluorescence induction O-J-I-P transients. Photosynthetica 44:69-75

23. Panda D, Sharma SG, Sarkar RK (2008) Chlorophyll fluorescence parameters, $\mathrm{CO}_{2}$ photosynthetic rate and regeneration capacity as a result of complete submergence and subsequent re-emergence in rice (Oryza sativa L.). Aquatic Bot 88:127-133

24. Pezeshki SR (2001) Wetland plants responses to soil flooding. Environ Exp Bot 46:299-312

25. Pfannschmidt T (2003) Chloroplast redox signals: how photosynthesis controls its own genes. Trends Plant Sci 8:33-41

26. Porra RJ (2002) The chequered history of the development and use of simultaneous equations for accurate determination of chlorophylls a and b. Photosynth Res 73:149-156

27. Ramakrishanayya G, Setter TL, Sarkar RK, Krishnan P, Ravi I (1999) Influence ofphosphorous application on oxygen concentrations and survival of rice during complete submergence. Exp Agric 35:167-180

28. Rao MV, Hale BA, Ormrod DP (1995) Amelioration of ozone induced oxidative damage in wheat plants grown under high carbon dioxide: role of antioxidant enzyme. Plant Physiol 109: 421-432

29. Sarkar RK (1998) Saccharide content and growth parameters in relation with flooding tolerance in rice. Biol Plant 40:597-603

30. Sarkar RK, Bhataacharjee B (2011) Rice genotypes with SUB1 QTL differ in submergence tolerance, elongation ability during submergence and re-generation growth at re-emergence. Rice 4:50-65. doi:10.1007/s12284-011-9065-z

31. Sarkar RK, Reddy JN, Sharma SG, Ismail AM (2006) Physiological basis of submergence tolerance in rice and implications for crop improvement. Curr Sci 91:899-906

32. Sarkar RK, Panda D, Reddy JN, Patnaik SSC, Mackil DL, Ismail AM (2009) Performance of submergence tolerant rice (Oryza sativa) genotypes carrying the Sub1 quantitative trait locus under stressed and non-stressed natural field conditions. Indian J Agric Sci 79:876-883

33. Shigeoka S, Yokota A, Nakano Y, Kitaoka S (1979) The effect of illumination on the L- ascorbic acid content in Euglena gracillis Z. Agric Biol Chem 43:2053-2058

34. Smirnoff N (1996) The function and metabolism of ascorbic acid in plants. Ann Bot 78:661-669

35. Sun Z-L, Lee H-Y, Matsubara S, Hope AB, Pogson BJ, Hong Y-N, Chow WS (2006) Photoprotection of residual functional photosystem II units that survive llumination in the absence of repair, and their critical role in subsequent recovery. Physiol Plant 128:415-424

36. Yordanova RY, Christov KN, Popova LP (2004) Antioxidative enzymes in barley plants subjected to soil flooding. Environ Exp Bot 51:93-101

37. Yu-Chun D, Nose A, Kawamitsu Y, Murayama S, Wasano K, Uchida Y (1996) An improved spectrophotometric determination of the activity of ribulose 1,5 , bisphosphate carboxylase. Jap J Crop Sci 65:714-721 